\title{
STUDIES ON PROTEIN BINDING OF ANTIBIOTICS
}

\section{EFFECT OF APALCILLIN ON PROTEIN BINDING AND PHARMACOKINETICS OF CEFOPERAZONE AND CEFAZOLIN}

\author{
Yasuo Watanabe, Toshio Hayashi, Rieko Kitayama, Takashi Yasuda, \\ ISAMU SAIKAWA and KiHACHIRo ShimizU*
}

\author{
Research Laboratory, Toyama Chemical Co., Ltd., Toyama, Japan \\ *Department of Internal Medicine, Tokyo Women's Medical College, Tokyo, Japan \\ (Received for publication March 23, 1981)
}

\begin{abstract}
The drug-protein interactions between cefoperazone (CPZ) and apalcillin (APPC), and between cefazolin (CEZ) and APPC were investigated in in vitro and in vivo experiments. Though the binding rates of $\mathrm{CPZ}$ or CEZ to rabbit serum and human serum albumin subsided remarkably with increased drug concentrations, APPC was not greatly affected, even at high concentrations. It appeared that APPC had a higher binding capacity to protein than CPZ or CEZ. From the results of competitive study, it became clear that APPC partially shared the binding sites on protein with CPZ or CEZ.

The CPZ or CEZ serum levels in rabbits administered together with APPC were not different from those for the single administration, but APPC levels for the simultaneous administration were slightly lower.
\end{abstract}

In our previous paper ${ }^{1)}$, the serum protein binding of cefoperazone (CPZ, T-1551) and cefazolin (CEZ), whose main excretion route is different, were investigated. It is reported that both have a similar degree of binding to serum protein and that they compete with one another for the binding sites on protein. Moreover, when both drugs are simultaneously administered, the serum level of each drug is significantly reduced, compared with that for the single administration, and subsequent excretion in urine increases due to an increase in the level of unbound drug.

The studies concerning the protein binding of antibiotics are almost solely concerned with determining binding rates, because it is important that the free drug is available for distribution to the tissues to exert a therapeutic effect. Very little attention has been paid to the binding mechanism of antibiotics ${ }^{2)}$. In particular, changes in the binding rates and pharmacokinetics of antibiotics simultaneously administered with other drugs have not been investigated, since it is difficult to determine the concentrations by bioassay.

In the present paper, in order to clarify the drug-protein interactions, we selected apalcillin (APPC $)^{32}$, which has a high protein binding, and investigated the effect of APPC on the protein binding and pharmacokinetics of CPZ or CEZ.

\section{Materials and Methods}

\section{Drugs}

Cefoperazone (CPZ, T-1551) was prepared by the Research Laboratory, Toyama Chemical Co., Ltd., Toyama, Japan. Cefazolin (CEZ) was produced by Fujisawa Pharmaceutical Co., Ltd., Osaka, Japan, and apalcillin (APPC) by Sumitomo Chemical Co., Ltd., Osaka, Japan. 
Animals

Japanese white adult male rabbits were used, weighing $2.0 \sim 3.0 \mathrm{~kg}$.

Drug Administration

Solutions of the drugs were prepared in saline. APPC $(20 \mathrm{mg} / \mathrm{kg})$ was administered alone and with $20 \mathrm{mg} / \mathrm{kg}$ of CPZ or CEZ into auricular vein.

Determination of Binding Rate and Displacement Activity

For determining the binding rate, the centrifugal ultrafiltration technique was used. The interference by APPC in the binding of CPZ or CEZ to serum protein was evaluated by the KLOTZ et al's $\operatorname{method}^{4)}$. The exact procedure was described in the previous repor $t^{1)}$.

Measurement of Antibiotic Concentration

Measurement of the antibiotic concentration was performed with a high pressure liquid chromatograph (HPLC, Shimadzu LC-2). Samples were run on a column $(250 \mathrm{~mm} \times 4 \mathrm{~mm} \phi)$ of LiChrosorb RP-18 at an ambient temperature and a flow rate of $1.0 \mathrm{ml} /$ minute. The mobile phase consisted of $14.5 \% \mathrm{CH}_{3} \mathrm{CN}, 1.4 \% 1 \mathrm{M} \mathrm{CH} \mathrm{CH}_{3} \mathrm{COOH}$ and $2.7 \% 1 \mathrm{M}\left(\mathrm{C}_{2} \mathrm{H}_{5}\right)_{3} \mathrm{~N} \cdot \mathrm{CH}_{3} \mathrm{COOH}$ in water for $\mathrm{CPZ}, 12.5 \%$ $\mathrm{CH}_{3} \mathrm{CN}, 1.4 \% 1 \mathrm{M} \mathrm{CH}_{3} \mathrm{COOH}$ and $2.7 \% 1 \mathrm{M}\left(\mathrm{C}_{2} \mathrm{H}_{5}\right)_{3} \mathrm{~N} \cdot \mathrm{CH}_{3} \mathrm{COOH}$ in water for CEZ, and for APPC, $18 \% \mathrm{CH}_{3} \mathrm{CN}$ in $0.05 \mathrm{M}$ phosphate buffer ( $\mathrm{pH} 5.0$ ). The eluate was monitored at $254 \mathrm{~nm}$.

\section{Results and Discussion}

1. In Vitro Displacement between $\mathrm{CPZ}$ and $\mathrm{APPC}$, and between $\mathrm{CEZ}$ and $\mathrm{APPC}$

As shown in Fig. 1, the binding rates of $\mathrm{CPZ}$ to rabbit serum varied from $95.2 \% \sim 46.6 \%$ in the final concentrations of the drug, ranging between $0.7 \times 10^{-4} \mathrm{M}$ and $12.0 \times 10^{-4} \mathrm{M}(50 \mu \mathrm{g} / \mathrm{ml} \sim 800 \mu \mathrm{g} / \mathrm{ml})$, while APPC binding varied from $81.6 \% \sim 64.4 \%$, ranging between $0.7 \times 10^{-4} \mathrm{M}$ and $12.0 \times 10^{-4} \mathrm{M}(40 \mu \mathrm{g} /$ $\mathrm{ml} \sim 640 \mu \mathrm{g} / \mathrm{ml})$. Thus, the binding rates of CPZ were radically decreased above $3.0 \times 10^{-4} \mathrm{M}(200 \mu \mathrm{g} /$ $\mathrm{ml}$ ), however, those of APPC did not greatly change even at high concentrations. The addition of APPC did not appear to influence the binding rate of CPZ, but APPC binding rates were decreased by approxi-

Fig. 1. Competitive binding between CPZ and APPC.
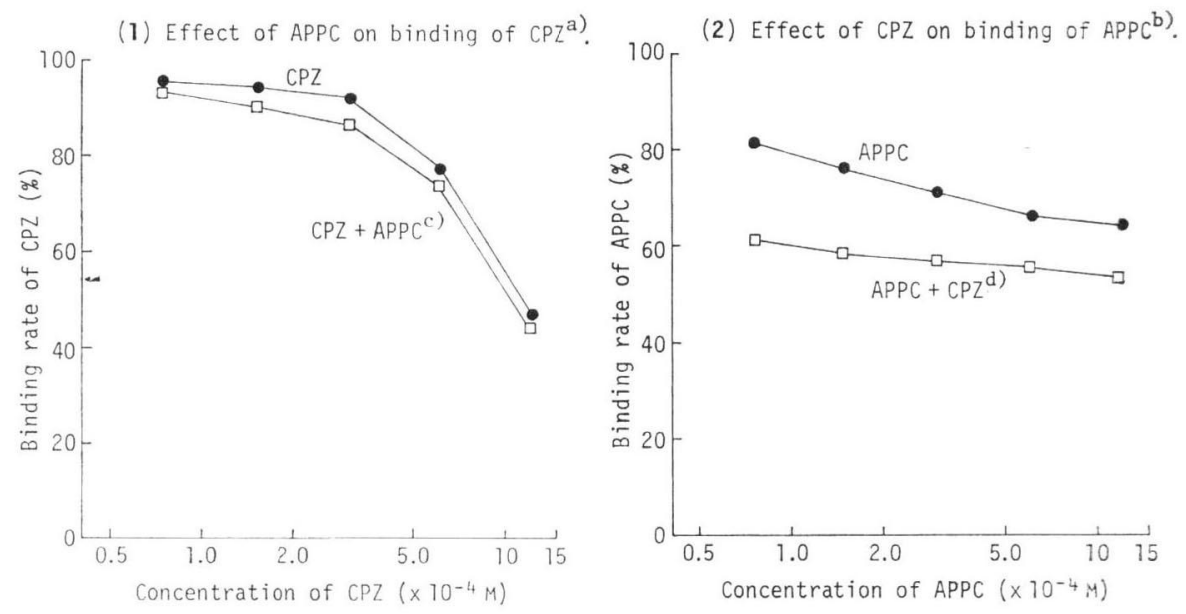

Protein: Rabbit serum. Method: Centrifugal ultrafiltration.

a) Binding rate of $\mathrm{CPZ}$ in the absence and presence of APPC.

b) Binding rate of $\mathrm{APPC}$ in the absence and presence of $\mathrm{CPZ}$.

c) APPC: $5.9 \times 10^{-4} \mathrm{M}(320 \mu \mathrm{g} / \mathrm{ml})$.

d) CPZ: $6.0 \times 10^{-4} \mathrm{M}(400 \mu \mathrm{g} / \mathrm{ml})$. 
Fig. 2. Competitive binding between CEZ and APPC.
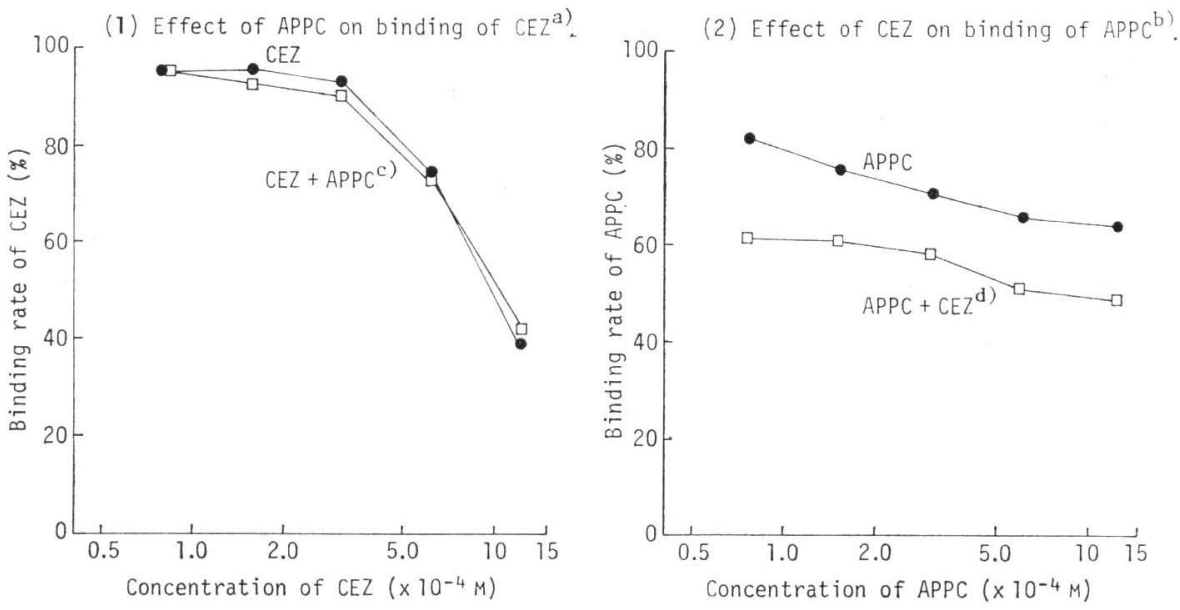

Protein: Rabbit serum. Method: Centrifugal ultrafiltration.

a) Binding rate of CEZ in the absence and presence of APPC.

b) Binding rate of APPC in the absence and presence of CEZ.

c) APPC: $5.9 \times 10^{-4} \mathrm{M}(320 \mu \mathrm{g} / \mathrm{ml})$.

d) CEZ: $5.9 \times 10^{-4} \mathrm{M}(280 \mu \mathrm{g} / \mathrm{ml})$.

Fig. 3. Competitive binding between $\mathrm{CPZ}$ and APPC, and between CEZ and APPC.
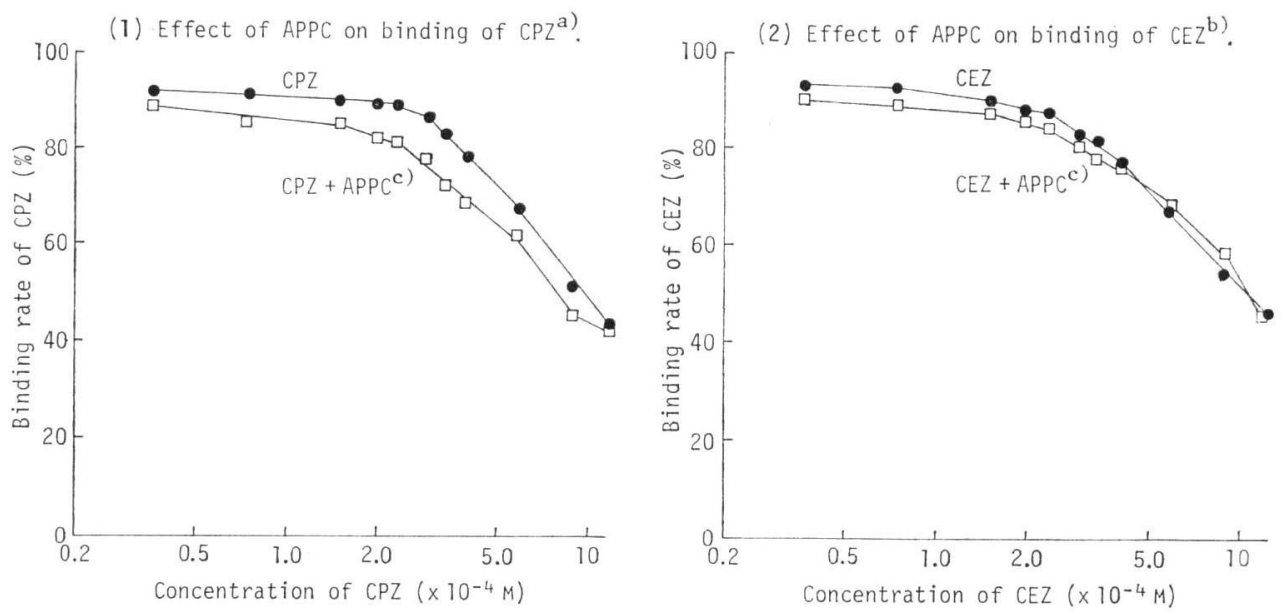

Protein: Human serum albumin $\left(5.8 \times 10^{-4} \mathrm{M}: 4 \%\right)$. Method: Centrifugal ultrafiltration.

a) Binding rate of $\mathrm{CPZ}$ in the absence and presence of APPC.

b) Binding rate of $\mathrm{CEZ}$ in the absence and presence of APPC.

c) APPC: $5.8 \times 10^{-4} \mathrm{M}(315 \mu \mathrm{g} / \mathrm{ml})$.

mately $10 \sim 20 \%$ by the addition of CPZ. Similar results were obtained for CEZ (Fig. 2).

In order to investigate these results in detail, human serum albumin was applied. As with rabbit serum, CPZ and CEZ were not influenced by the addition of APPC (Fig. 3). Using the formula of KLOTZ et al. ${ }^{4}$, a linear relationship was demonstrated between the reciprocal of the concentration of unbound drug and the reciprocal of the moles of drug bound per mole of albumin (Fig. 4). The inter- 
Fig. 4. KLOTZ plots for binding of CPZ and CEZ to human serum albumin.
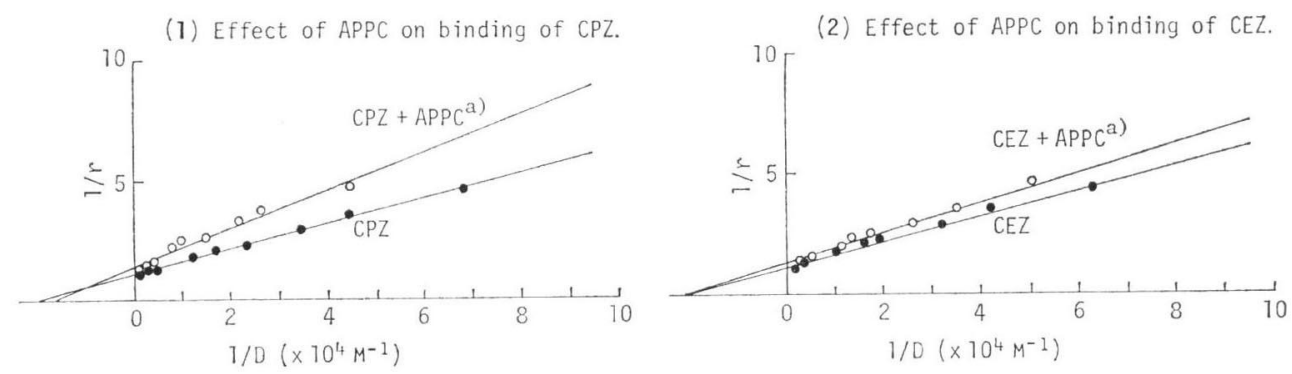

Human serum albumin: $5.8 \times 10^{-4} \mathrm{M}$.

r: Amount of bound drug per one molecule.

D: Free drug concentration.

a) APPC: $5.8 \times 10^{-4} \mathrm{M}(315 \mu \mathrm{g} / \mathrm{ml})$.

ference of APPC in CPZ binding to serum protein implied that both drugs partially shared the binding sites. APPC appeared to possess a poor displacing activity against $\mathrm{CPZ}$ or CEZ and did not alter the protein binding of $\mathrm{CPZ}$ or CEZ to human serum albumin. The interference of APPC in CEZ binding was somewhat less than that in $\mathrm{CPZ}$ binding.

From these results, at least four possible explanation can be offered to account for the difference between the behavior of APPC and that of CPZ or CEZ.

The first possible explanation lies in the high binding capacity of APPC to serum protein, compared with $\mathrm{CPZ}$ or $\mathrm{CEZ}$, i.e., though $\mathrm{CPZ}$ or $\mathrm{CEZ}$ was saturated at high concentrations, APPC was not.

A secound explanation is that APPC has a lot of binding sites differed from those of $\mathrm{CPZ}$ or CEZ, while the binding sites of CPZ approximately coincided with those of CEZ in the previous study ${ }^{1}$.

The third option is that APPC partially shared the binding sites of CPZ or CEZ and has a lower affinity to the shared sites.

The final possibility is that the main binding site of APPC on protein is different from that of $\mathrm{CPZ}$ or CEZ.

\section{Alteration of Serum Levels of CPZ and CEZ by APPC}

The serum levels of CPZ and CEZ, with and without APPC, were investigated in rabbits (Figs. 5, 6).

Though the CPZ levels after the simultaneous administration of APPC were not significantly different from those after the single administration, the level of APPC for the coadministration of CPZ was slightly lower $(\mathrm{P}<0.05)$ at 5 minutes than that for the single administration. Similar results were obtained for CEZ. These results appeared to coincide with the fact that the addition of APPC did not alter the binding rate of $\mathrm{CPZ}$ and CEZ, on the contrary, CPZ and CEZ reduced the APPC binding in the in vitro displacement study. Perhaps the increased free APPC is easily transferred into the tissues and available for glomerular filtration. These results are felt to be qualitatively similar to the previous results ${ }^{1)}$.

The present study showed that the binding behavior of APPC to serum protein was somewhat different from that of CPZ or CEZ.

Although several investigations concerning the protein binding of antibiotics have been undertaken $^{5,8)}$, details of the binding mechanism of drugs and the displacement between antibiotics still remain to be elucidated. 
Fig. 5. Serum levels of CPZ and APPC in rabbits.

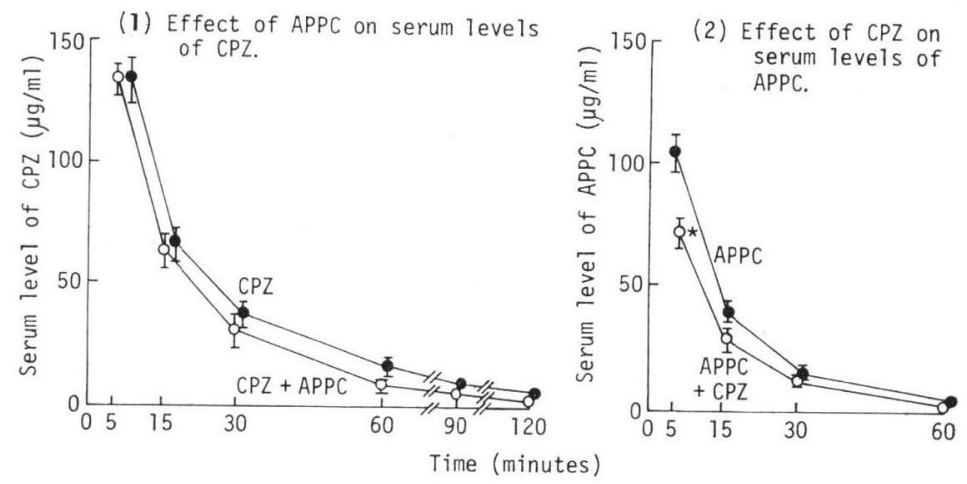

Rabbits were intravenously dosed with CPZ $(20 \mathrm{mg} / \mathrm{kg})$ and APPC $(20 \mathrm{mg} / \mathrm{kg})$, both separately and simultaneously. Each group consisted of 4 rabbits.

*: Significant difference at $\mathrm{P}<0.05$.

Fig. 6. Serum levels of CEZ and APPC in rabbits.
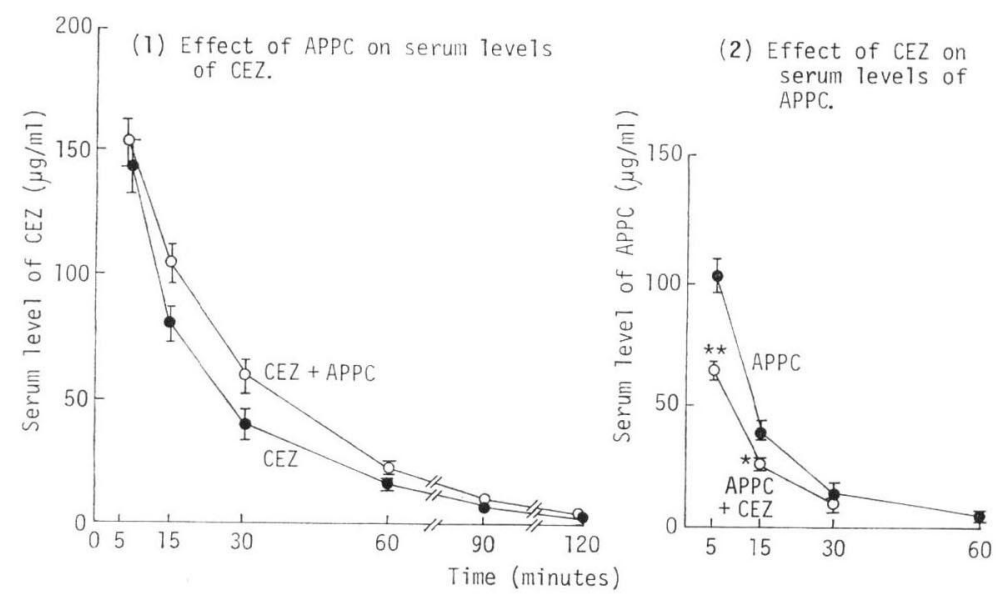

Rabbits were intravenously dosed with CEZ $(20 \mathrm{mg} / \mathrm{kg})$ and APPC (20 mg/kg), both separately and simultaneously.

*: Singificant difference at $\mathrm{P}<0.05$.

**: Significant difference at $\mathrm{P}<0.01$.

\section{References}

1) Watanabe, Y.; T. Hayashi, R. Takada, T. Yasuda, I. Saikawa \& K. Shimizu: Studies on protein binding of antibiotics. I. Effect of cefazolin on protein binding and pharmacokinetics of cefoperazone. J. Antibiotics 33: $625 \sim 635,1980$

2) Brand, J. G. \& T. Y. Toribara: Equilibrium dialysis and circular dichroic analysis of the novobiocinbovine serum albumin complex. Arch. Biochem. Biophys. 174: 541 545, 1976

3) Noguchi, H.; Y. EdA, H. Tobiki, T. NAKagome \& T. Komatsu: PC-904, a novel broad-spectrum semisynthetic penicillin with marked antipseudomonal activity: Microbiological evaluation. Antimicr. Agents \& Chemoth. 9: $262 \sim 273,1976$

4) Klotz, I. M.; H. Triwush \& F. M. WALker: The binding of organic ions by proteins. Competition phenomena and denaturation effect. J. Am. Chem. Soc. 70: 2935 2941, 1956

5) Kunin, C. M.; W. A. Craig, M. Korngutch \& R. Monson: Influence of binding on the pharmacologic activity of antibiotics. Ann. N. Y. Acad. Sci. 226: 214 224, 1973

6) Daiton, P. G.; Z. H. Israili \& J. M. Perel: Influence of binding on drug metabolism and distribution. Ann. N. Y. Acad. Sci. 226: $172 \sim 194,1973$ 